\title{
A subglacial microbial methane sink
}

Antarctic subglacial lakes are largely unexplored frontiers that play host to dynamic microbial ecosystems. Among the organisms present are several that either produce or consume $\mathrm{CH}_{4}$ as an important energy vector. New research explores subglacial biogeochemical cycling by analysing $\mathrm{CH}_{4}$ isotopologues and bacterial genes and species from Subglacial Lake Whillans (SLW), which sits beneath the West Antarctic Ice Sheet (WAIS). A team led by Alexander Michaud reports its findings in Nature Geoscience, revealing that a microbial community beneath SLW acts as a $\mathrm{CH}_{4}$ sink that might mitigate large-scale release of this greenhouse gas as ice sheets retreat.

Mapping the biogeochemical $\mathrm{CH}_{4}$ cycle required Michaud and colleagues to probe below SLW. "We had never drilled through $800 \mathrm{~m}$ of ice before," stresses Priscu, the Chief Scientist for SLW sampling efforts. "Once we had determined that there was life, it was time to address how microbial processes beneath large ice sheets participate in biogeochemical cycles," adds Michaud. In the anoxic sediments beneath SLW, they found that hydrogenotrophic methanogenesis - the reduction of $\mathrm{CO}_{2}$ to $\mathrm{CH}_{4}$ using $\mathrm{H}_{2}-$ is prevalent.

Sediment $39 \mathrm{~cm}$ below the lake contains significantly more $\mathrm{CH}_{4}(300 \mu \mathrm{M})$ than does the lake itself $(0.024 \mu \mathrm{M})$, such that $6.8 \pm 1.8 \mathrm{mmol}$ $\mathrm{CH}_{4} \mathrm{~m}^{-2} \mathrm{yr}^{-1}$ pass upward through the sediments to the lake water. The authors measured the relative isotopic abundances in SLW sedimentary $\mathrm{CH}_{4}$, and the natural variations provided a 'fingerprint' that revealed clues regarding its origin. The $\mathrm{CH}_{4}$ concentrations, as well as $\delta^{13} \mathrm{C}-\mathrm{CH}_{4}$ and $\delta^{2} \mathrm{H}-\mathrm{CH}_{4}$ values (the extent to which the quotients ${ }^{13} \mathrm{C} /{ }^{12} \mathrm{C}$ and ${ }^{2} \mathrm{H} /{ }^{1} \mathrm{H}$ in $\mathrm{CH}_{4}$, respectively, depart from standard values), provide evidence for hydrogenotrophic methanogenesis. The resulting $\mathrm{CH}_{4}$ diffuses upwards and is oxidized by bacteria at the sediment/water interface.

Michaud and colleagues calculate that $>99 \%$ of sub-ice-sheet $\mathrm{CH}_{4}$ is oxidized at the sediment/water interface, a finding supported by a large positive shift in $\delta^{13} \mathrm{C}-\mathrm{CH}_{4}$. Their results challenge earlier models that emphasized the significance of a possible subglacial $\mathrm{CH}_{4}$ flux into the atmosphere. The authors attribute $\mathrm{CH}_{4}$ consumption to oxidation by aerobic methanotrophs in surficial sediment, with $\mathrm{O}_{2}$ sourced from basal melting of the WAIS. These active SLW methanotrophs may be a globally important $\mathrm{CH}_{4}$ sink; conversion of sedimentary $\mathrm{CH}_{4}$ efflux into $\mathrm{CO}_{2}$ and biomass may act as a 'buffer' and lessen the warming potential of subglacial gases that escape as ice sheets retreat.

Having established the flow of $\mathrm{CH}_{4}$, the team sought to find out which organisms were trading this currency. "Molecular microbiological data complement the geochemical analyses," says Michaud. "Together, these methods allow us to say that methane is being consumed by known methane-oxidizing bacteria." pmoA genes, which encode particulate methane monooxygenases (enzymes that enable methanotrophy in the $\mathrm{O}_{2}$-rich SLW regions), were found in the SLW sediment. Chemical affinity calculations also implicate aerobic $\mathrm{CH}_{4}$ oxidation as the most energetically favourable process for sustaining microorganisms in SLW surficial sediment (whereas the oxidation of both $\mathrm{FeS}_{2}$ and $\mathrm{NH}_{4}{ }^{+}$is more favorable in the SLW water column). The $p m o A$ sequences and community analysis of $16 \mathrm{~S}$ rRNA genes indicated that SLW, particularly in surficial sediments, is home to Methylobacter tundripaludum and other methanotrophs. $M$. tundripaludum is an aerobic cold-adapted bacterium that oxidizes $\mathrm{CH}_{4}$ to eventually produce $\mathrm{CO}_{2}$ and biomass, with the product ratio being dependent on $\mathrm{O}_{2}$ supply and energy requirements.

\section{it was time to} address how microbial processes beneath large ice sheets participate in biogeochemical cycles

Given the role of $\mathrm{CH}_{4}$ in climate forcing, understanding its sources, sinks and feedbacks is paramount. Priscu is now leading a second project (SALSA) - one that will involve drilling beneath Subglacial Lake Mercer, a deeper and larger system that may reveal more about biogeochemical cycling beneath the Antarctic ice sheet. "I was not surprised that we found life in Subglacial Lake Whillans. I was surprised, however, by the diversity of life we found and the biogeochemical transformations associated with this life," says Priscu.

Sinéad Lyster

ORIGINAL ARTICLE Michaud, A. B. et al. Microbial oxidation as a methane sink beneath the West Antarctic Ice Sheet. Nat. Geosci. http://dx.doi.org/10.1038/NGEO2992 (2017) WEB SITES

Whillans Ice Stream Subglacial Access Research Drilling (WISSARD) project: http://www.wissard.org/

Subglacial Antarctic Lakes Scientific Access (SALSA) project: https://salsa-antarctica.org/ 